\section{Back to the} Future?

\section{A Response to Dilevko and} Magowan
Neil Hollands,

\section{Guest Columnist}

Correspondence concerning this column should be addressed to

Barry Trott, Adult Services Director, Williamsburg Regional Library, 7770 Croaker Rd., Williamsburg, VA 23188; email:btrott@mail.wrl.org.

Neil Hollands is an Adult Services Librarian at the Williamsburg (Va.) Regional Library, where he works as part of the library's RA team and coordinates the award-winning, profile-based readers' advisory service, Looking for a Good Book. Hollands has been a presenter at the Public Library Association, Virginia Library Association, and Connecticut Library Association conferences, and has provided training for various library systems. His first book, Read On ... Fantasy Fiction, was published in 2007 by Libraries Unlimited.
Readers' advisory (RA) services have a long history in United States public libraries. Since the late nineteenth century, there always has been a component of public library services that has focused on connecting readers with books. As RA services have developed, contemporary practices have generally built on the foundations established by previous generations of readers' advisors. In their book, Readers' Advisory Service in North American Public Libraries, 1870-2005, Juris Dilevko and Candice F. C. Magowan look at these foundations of RA services, and then call into question the work of contemporary readers' advisors. ${ }^{1}$ The authors present a highly critical view of RA as it has developed in the past two decades. Among librarians who work with readers on a daily basis, Dilevko and Magowan's work has generated controversy for its harsh critique of contemporary RA practice and theory. In the following article, Neil Hollands examines Dilevko and Magowan's thesis and addresses the criticisms of contemporary RA theory and practice that the authors raise.—Editor

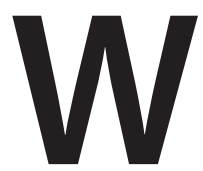
here are we going, where have we been? Those are questions that come to mind as a contemporary librarian reads Juris Dilevko and Candice F. C. Magowan's Readers' Advisory Service in North American Public Libraries, 1870-2005. Their book is ostensibly a history of RA service in public libraries, but from the first sentences it is apparent that "history" will be molded to serve the authors' arguments about what RA service should be. Dilevko and Magowan seek to revise the way in which we look at RA's history, and, in doing so, lead a reactionary movement toward a future in which advisory is practiced as it was in the past, not as it is in the present. The authors have strong opinions, but ultimately their conclusions are wrongheaded. Nonetheless, examination of these opinions serves to remind us of the philosophy behind contemporary RA service, and thus can inform our goals for future practice.

Dilevko and Magowan's central thesis is that contemporary literature has become commodified, concerned only with the profitability of books and their use to cross-promote other products. They believe that, beginning in the late 1960s, under the influence of the "Give 'Em What They Want" movement, RA in public libraries was steadily co-opted by corporate culture. Readers' advisors, they argue, have devolved into little more than marketers (perhaps knowingly, perhaps not) for dumbed-down, narcissistic literature to the detriment of readership for classics and serious nonfiction. Even worse, they claim, our emphasis on appeal factors, technological 


\section{READERS' ADVISORY}

tools such as the NoveList database, and categorized book lists is leading to "McProfiling," a deskilling of the profession that will ultimately lead to our replacement by machines and paraprofessionals.

\section{HISTORY'S REFLECTION ON THE PRESENT: TWO VIEWS}

Instead of the current RA model, as defined by Joyce Saricks, Duncan Smith's NoveList, the Genreflecting series, Nancy Pearl, and others, Dilevko and Magowan propose that RA be remodeled in the fashion of what they consider its glory days, 1917 to 1962, an era which they believe was "committed to systematic adult education."' In that era, they hold, readers' advisors were subject experts who could separate literary wheat from the chaff and design systematic reading courses in subjects that would help undereducated adults "get somewhere." The authors seem to have no argument with early library practices that actively discouraged fiction reading unless it was focused on "great books."

The best chapters of their book concern RA's history to 1962. This history will remind thoughtful practitioners that many interesting approaches to advisory have historical progenitors that deserve exploration. If the authors had stopped here and drawn reasonable conclusions - that RA's educational and therapeutic aspects deserve renewed attention; that systematic reading courses supporting self-education in practical topics might be a good addition to promotion of popular materials; that advisors might find inspiration in historical ideas, such as the belief that every librarian should be a capable readers' advisor- this would be a valuable book for practitioners.

But Dilevko and Magowan have an ideological axe to grind. To do so, they make claims for their "history" that go beyond the boundaries of any evidence. Rhetoric used to promote adult education programs in the early twentieth century is taken as proof of their superiority to modern approaches, but there is little evaluation of how well these programs met educational goals or were received by readers. One cannot help but notice that almost all of these programs were confined to the largest American cities, where some budgets might once have supported full research libraries and staffs may, historically, have been large enough to maintain subject experts.

Dilevko and Magowan present egregious examples of abusive practices in contemporary publishing and marketing, then generalize these extremes to larger classes. Because examples of ridiculous cross-media promotion exist, they believe all of contemporary literature is commodified. Because some bookstores and online sellers will sell product placements, all bestsellers are found fraudulent. Because there are some questionable or overly specialized literary awards, all award-winning books are condemned. And because a few genre books are produced according to publisher rules and templates, all of genre fiction is defined as stereotypical. On page after page, "genre titles, bestsellers, celebrity-authored books, and prize-winning titles" are lumped together for condemnation, as if these books were all of one ilk. These extremist positions show a lack of education about contemporary literature. Dilevko and Magowan could use a good advisor to steer them away from books whose advertising surpasses their quality, and, if it is what they want, toward bestsellers, genre fiction, and award-winners with literary heft.

But therein lies the problem: Dilevko and Magowan wouldn't consult a readers' advisor. Time and again in their analysis, they hold the judgment and interpretive skills of contemporary public librarians and readers in contempt. According to them, we have a Pavlovian response to every marketing ploy, drooling on command when confronted with a mass-marketed book. Another criticism that appears repeatedly in the book is that modern readers want "less Rembrandt, more me." (The authors frequently indulge in the kind of mindless slogans that pervade the commodified culture they so condemn.) Any attempt by readers to pursue their own agendas is dismissed as narcissistic self-satisfaction driven by unseen commercial forces. This elitism is ultimately self-defeating: one can't build the future of a public service on a foundation of contempt for the public.

The authors don't exhibit knowledge of public library practice and apparently chose not to talk to the advisors whom they vilify. As a result, they frequently misrepresent those librarians' working methods. Instead, they characterize modern practice with more slogans. Contemporary RA, according to Dilevko and Magowan, is dominated by two forces: an extreme version of "Give 'Em What They Want" populism promoted by Charlie Robinson at Baltimore County Public Library that "deskills" the profession through knee-jerk promotion of popular culture, and overreliance on lists and weak technical tools that they claim leads to the "McProfiling" of readers through the fragmenting prism of appeal factors. ${ }^{3}$ Each of these claims deserves a response.

\section{GIVE 'EM WHAT THEY WANT, BUT LISTEN TO THEM FIRST}

While it is true that modern RA does try to give readers what they want, characterizing contemporary RA as an extension of the classics-bashing, antiprofessional librarian philosophy of Baltimore County director Charlie Robinson is wrong. Advisors give readers what they want not by buying more copies of the bestsellers, as Robinson might have done, nor by forcing a great book on them, as Dilevko and Magowan would do, but by listening to how they describe their reading experiences and desires and then finding a mix of books that are likely to appeal to them and further their personal goals.

If the authors had talked to more practicing readers' advisors, they would find that we serve readers with many goals. It's true that many readers seek out light reading and genre titles as a way of diverting themselves for a few moments from the complications of their everyday lives. They don't apologize for this goal, and, as advisors, we don't apologize for supporting them. But we also serve plenty of readers who love 
the challenge of the classics and great books. Nor is advisory as simple as a choice between these two extremes. In a single RA conversation, we often point a reader toward a mixture of light, quick fun and more complex works.

Throughout their book, Dilevko and Magowan create a false dichotomy, taking the position that light reading and great books are somehow mutually exclusive. This couldn't be farther from the truth. If they would rely less on the casual snobbery and cocktail-party theorizing of conservative culture critics, and more on reading research, they would know that people who read light fiction are more likely to read great books and complex nonfiction than the average person. But light fiction isn't just a path to the great books. If the authors had RA experience, they would know that readers are capable of pulling great insights from light fiction.

While characterizing contemporary RA as an extension of publisher marketing is wrong, there may be a grain of truth to the authors' position. In our general enthusiasm for reading, advisors may become caught up in promoting books that we know have limited charms but will circulate easily. Some books are advertised more than enough without the advisory community adding to their readership. Without violating our tenets of matching book to reader, we can still seek out the best books within all genres at all levels of difficulty and all measures of appeal.

But to characterize RA librarians on the whole as purveyors of commodified mediocrity is false. We are strong advocates for exceptional books. We seek out excellent titles, both new and old, and promote them relentlessly. The advisors I know are greatly concerned when mediocrities outsell books that will stand the test of time. We campaign tirelessly for the excellent low- and mid-list authors that our readers enjoy upon discovery. We work hard to find audiences for the long tail of lesser-known authors and older books that fill the shelves of our buildings. The advisors I know certainly demonstrate more awareness of excellent books than Dilevko and Magowan, who in two hundred pages don't have a single kind word for a living fiction author.

Where we differ with the authors is in our insistence that readers should not apologize for their tastes. We disagree with the outdated practice of shaming people for what they enjoy. We do not believe that only literature professors can identify a good book. We trust readers to know when a book has served a purpose for them. There is subtlety and balance in the RA process. We can recommend excellent books that are germane to a reader's interests without defaming or shunting aside the books that gave them a love of reading in the first place.

\section{DEALING WITH THE READER AS A WHOLE: THE USE OF APPEAL FACTORS}

Dilevko and Magowan's next targets are the lists, books, and databases used by readers' advisors. They believe that categorizing books within these tools fragments the reading public into ever-diminishing subgenres that become target audiences for publishers. Further, they characterize the development of appeal factor theory by Joyce Saricks and others as part of this attempt to mechanically define readers and then pigeonhole their reading to a particular subgenre. Any attempt by advisors to make the practice of finding books easier or more efficient is considered evidence for their characterization of contemporary RA as a mindless, automated process. They strongly imply that our final goal is the elimination of human librarians altogether.

Again, there are glimmers of truth in this position. There is a potential for librarians to become too engrossed in subdividing books into categories, to collect books into lists just because we can. While limits on our resources do require that we seek efficiency in providing readers' advisory, RA should not be reduced to a simple process of pigeonholing readers into categories. Admittedly, our tools are not perfect. The literature of RA and the databases on the market are works in progress - a mix of high quality and missed potential.

But again, Dilevko and Magowan's characterization of RA practice is incorrect on the whole. They misunderstand the way in which appeal factors are used. The language of appeal, when used correctly, attempts to describe the complex totality of a given reader's preferences, to inventory that reader's values, not reduce them to a single category. The goal is not to provide only books that exactly match every single preference, but to make sure that the collection of books we suggest to the reader on the whole will address their interests and needs. A good readers' advisor provides some books that are right down the middle of the reader's interests, and others that provide room for small stretches in new, but related, directions. A good advisor can use the language of appeal to help the reader understand his or her reading history and how the books that are suggested address, and sometimes subtly vary, from those preferences.

When the authors turn to case studies of contemporary RA tools, they again resort to an unfair, reductive characterization of advisory service. ${ }^{4}$ In their study of NoveList, they asked students to use simple keyword searches to generate readalikes for their favorite novels. After trying one of these novels, the students critiqued the service. The process used for the case study failed to include more complex kinds of searching that are possible with the database and, in particular, ignored all of the value-added content that NoveList contributors have written. Nancy Pearl's Book Lust is given similar treatment; its brief, entertainment-focused reading lists are subjected to a scholarly critique that isn't appropriate for the format or the stated intentions of the book. ${ }^{5}$

More important, both of these case studies lack an important component of advisory: the advisor. A good advisor would use these tools with the reader to help generate ideas, then follow up with further analysis of what appeals to the reader to narrow (and sometimes broaden) the list of future reading possibilities. Dilevko and Magowan might remind us that too many shortcuts result in shoddy service, but their case studies are ultimately tantamount to snacking only on raw ingredients from a chef's kitchen, then complaining about the quality of the cuisine. 


\section{READERS' ADVISORY}

Dilevko and Magowan offer generic and impractical alternatives to appeal factor analysis. Referring vaguely to "historical resonance" and the "rich and complex totality" of great books, they would offer nothing to readers but the admonition that they should wait and take the classics department's word on what is great literature. Their dismissal of appeal factor analysis as nothing more than an efficiency measure begs the question of how they would evaluate works of fiction. Apparently great works of literature emerge from writers as did Athena from the forehead of Zeus. Dilevko and Magowan complain about the deskilling of librarianship, but they would leave librarians with little to do but pass out a short list of great books to bewildered patrons.

Appeal factor analysis bears a close relation to the kind of thinking engaged in by students and critics of literature. It is the practical application of this kind of thinking to the experiences, needs, and desires of the individual reader. Limitations in the tools that advisors use come not from overuse of this kind of analysis, but from incompleteness in its application. When subject and character-type headings in NoveList produce matches that are inaccurate, it is because other appeal factors, such as language, tone, and pacing, have not been addressed. When a list of books with a common setting produces a wildly varied grouping, it is the task of the skilled RA professional to augment that list with further analysis and interpretation of its contents.

\section{CONCLUSION}

In the end, the lack of reading research in Dilevko and Magowan's book is telling. The authors don't have a coherent story about how the great books reading they espouse will create the ends they desire. They quote the research of Catherine Sheldrick Ross, but don't seem to understand its significance. Ross identifies many needs served by many kinds of books, including finding "models for identity," "new perspectives and enlargement of possibilities," "confirmation of self-worth," "connection with others and awareness of not being alone," "courage to make change," and better "understanding of the world." To this list of reading benefits and goals we can add the social value of reading books that others have read; the education derived from information woven deftly into entertaining fiction and nonfiction narratives; the challenge of reading books that enhance our vocabularies and our ability to decipher complex ideas; and the needed diversion sometimes provided by light reading. Helping readers in all of these pursuits is the philosophical underpinning of exemplary contemporary RA. By finding books that fulfill these varying needs, readers' advisors create the kind of moral education the authors advocate.

Dilevko and Magowan dismiss Ross's research summarily as more lightweight, narcissistic, "fewer theologians, more dietitians" thinking, but they are wrong. Gaining empathy for others through encountering diverse characters in fiction is hardly narcissistic. Their account of how literature improves lives relies on pseudo-mystical anecdotes of how great books opened the windows of Andrew Carnegie's dungeon, allowed young Condoleeza Rice to pull herself up by her bootstraps, or solved the problems of those in nineteenth-century African-American literary societies. Dilevko and Magowan would use "books by Reinhold Niebuhr; Plato's Gorgias; courses about Ancient Greece, neuroscience, and statistics; and foreign-language courses" as "starting points" and kindly help those from "less-advantaged backgrounds" by giving them the works of "Thomas Hardy; the Greek Classics; and . . . the novels of Henry James." By somehow imprinting these books into the minds of beginning readers, they would claim to greatly improve society. This account is counterintuitive to any reasoned understanding of educational development.

Even if a retreat behind the walls of the great books was desirable, the authors have no suggestions whatsoever for implementation. One has to wonder how they would suggest people be made to read these great books before they have developed a facility for reading. Any experienced advisor could recount stories of youngsters turned off from reading by a teacher who forced complex works on them before they were ready, or of adults who stay away from books until they realize it is OK to read a book that is fun. They could tell you about how the brightest people they know are devoted to the genre fiction Dilevko and Magowan dismiss. One wonders what a devoted mystery reader such as Jacques Barzun or a science fiction fan such as Isaac Asimov would say if Dilevko told them that genre fiction was ruining their potential.

Dilevko and Magowan believe that Bernard Berelson's 1949 suggestions would make a good guide for libraries. ${ }^{8}$ Berelson believed we could measure library success in terms of "social, political, and psychological processes," such as the "promotion of group understanding, the clarification of the goals and values of the society, the encouragement of interest in politics, [and] the development of greater rationality in political decisions." ${ }^{\prime \prime}$ Ross's enumeration of the values of reading provides a clearer path to these goals than anything suggested by Dilevko and Magowan. When readers find confirmation of self-worth through romances, they enhance their psyches and become more able to participate in the social world. When they get new perspectives from Alexander McCall-Smith's optimistic detective Precious Ramotswe, Michael Connolly's tough-guy Harry Bosch, or the clever historical heroes of Dorothy Dunnett, they incorporate or reject the author's and character's philosophies, thus clarifying what they believe should be appropriate goals for society. Through consideration of hypothetical worlds such as George R. R. Martin's fantasies or Lois McMaster Bujold's Vorkosigan saga, they better understand the real world and become more interested in politics and making intelligent political decisions. And yes, if readers want to pursue these same goals through classics instead of genre fiction, contemporary RA can accommodate that as well.

Finally, Magowan and Dilevko's claim that contemporary RA practice somehow deskills librarianship is only true if we cannot identify worthwhile, challenging goals that need to be addressed for continuing RA improvement. When we 
start from our shared values of service, inclusiveness, respect for the interests and needs of all library users, and advocacy of good reading, then a set of ongoing challenges for professional readers' advisors becomes abundantly clear. We have much work to do, but contemporary RA is on the right track. Instead of retreating to the methods of the distant past, let's continue in evolving a high-quality service.

\section{References}

1. Juris Dilevko and Candice F. C. Magowan, Readers' Advisory Service in North American Public Libraries, 1870-2005 (Jefferson, N.C.: McFarland \& Co., 2007).

2. Ibid., 53.

3. Dilevko and Magowan, Readers' Advisory Service in North American Public Libraries.
4. Ibid

5. Nancy Pearl, Book Lust (Seattle: Sasquatch Books, 2003).

6. Catherine Sheldrick Ross, "Finding without Seeking: The Information Encounter in the Context of Reading for Pleasure," Information Processing and Management 335, no. 6 (1999): 793-95; "Making Choices: What Readers Say about Choosing Books to Read for Pleasure," The Acquisitions Librarian 25 (2001); Catherine Sheldrick Ross, Lynne McKechnie, and Paulette M. Rothbauer, Reading Matters: What the Research Reveals about Reading, Libraries, and Community (Westport, Conn.: Libraries Unlimited, 2005).

7. Dilevko and Magowan, Readers' Advisory Service in North American Public Libraries, 199-200.

8. Bernard Berelson, "Reply to the Discussants," in A Forum on the Public Library Inquiry: The Conference at the University of Chicago Graduate Library School, August 8-13, 1949, ed. Lester Asheim, 60-65 (New York: Columbia Univ. Pr., 1950).

9. Ibid., 64 . 